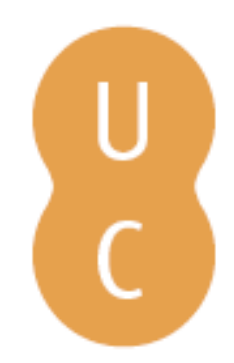

\title{
pompalina
}

\section{Workload and perception of effort in swin training}

\author{
Autor(es): $\quad$ Teixeira, Ana M.; Rama, Luís
}

Publicado por: Imprensa da Universidade de Coimbra

URL

persistente:

URI:http://hdl.handle.net/10316.2/38875

DOI:

DOI:http://dx.doi.org/10.14195/978-989-26-1171-6_12

Accessed : $\quad$ 26-Apr-2023 10:33:02

A navegação consulta e descarregamento dos títulos inseridos nas Bibliotecas Digitais UC Digitalis, UC Pombalina e UC Impactum, pressupõem a aceitação plena e sem reservas dos Termos e Condições de Uso destas Bibliotecas Digitais, disponíveis em https://digitalis.uc.pt/pt-pt/termos.

Conforme exposto nos referidos Termos e Condições de Uso, o descarregamento de títulos de acesso restrito requer uma licença válida de autorização devendo o utilizador aceder ao(s) documento(s) a partir de um endereço de IP da instituição detentora da supramencionada licença.

Ao utilizador é apenas permitido o descarregamento para uso pessoal, pelo que o emprego do(s) título(s) descarregado(s) para outro fim, designadamente comercial, carece de autorização do respetivo autor ou editor da obra.

Na medida em que todas as obras da UC Digitalis se encontram protegidas pelo Código do Direito de Autor e Direitos Conexos e demais legislação aplicável, toda a cópia, parcial ou total, deste documento, nos casos em que é legalmente admitida, deverá conter ou fazer-se acompanhar por este aviso.

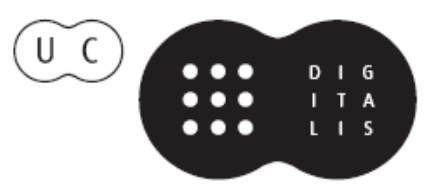



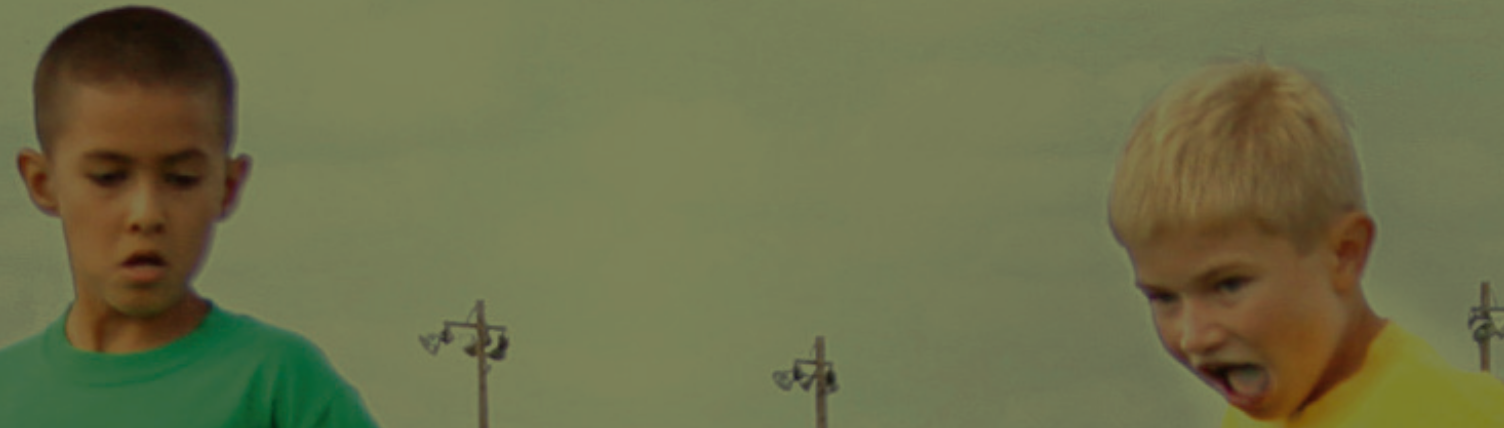

YOUTH SPORTS

\section{PARTICIPATION, $:$}

TRAINABHLTY TY

AND READINESSh

MANUEL J. COELHO E SILVA

ANTÓNIO J. FIGUEIREDO

MARIJE T. ELFERINK-GEMSER

ROBERT M. MALINA

EDITORS

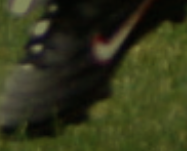

2. ${ }^{\circ}$ EDIÇÃO

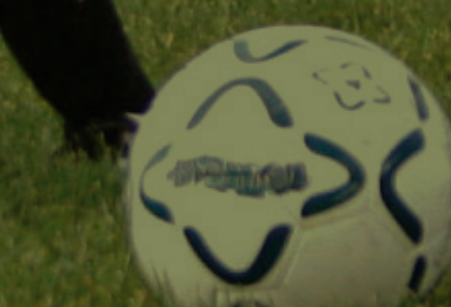

IMPRENSA DA

UNIVERSIDADE

DE COIMBRA

COIMBRA

UNIVERSITY

PRESS 


\section{CHAPTER 12: WORKLOAD AND PERCEPTION OF EFFORT IN SWIM TRAINING}

Ana M Teixeira

Luis Rama

\section{INTRODUCTION}

Knowledge of the effects of exercise on the conduction of training is important in reaching desired outcomes, especially when athletes undertake prolonged training loads. Several procedures can be followed to monitor these effects. The usual markers, especially physiological, are often invasive. The stressful character of this methodology, its associated cost, as well as the requirement of laboratories and specialized staff, make them relatively inaccessible to many in the sport community. However, it is possible to register of the subjective perception of effort or fatigue in order to estimate the influence of a specific training load on athletes.

Perception of effort scales were first introduced in cardiac rehabilitation as a way of monitoring the impact of exercises (Borg, 1985, 2000). It is also suggested the perception of effort is the best single indicator since it integrates several sources of information related to the muscles and joints directly involved, and the cardiovascular, respiratory and nervous systems (Borg et al 1985; Borg, 2000). The signs, perceptions and experiences are integrated into a global configuration labelled the perception of effort. These scales have been used to evaluate the fatigue or physiological stress in isolated tasks (Maglischo, 1993; Wilmore and Costill, 1994; Rushal, 1995). The validity of these instruments in activities that involve elevated indices of fatigue makes them very useful in the monitoring of training. Further, the technique involves the athlete as an active agent in the evaluation of effects resulting from the application of specific workloads.

This study evaluates two scales of perception of effort as indicators of accumulated training load in national and regional level competitive swimmers belonging to the same sport clubs and training together. Over the course of 26 weeks of a winter (short season), training load (volume and intensity of weekly training) was monitored in 23 national and 23 regional level swimmers. During each week of the training season, the swimmers recorded their perception of effort in each micro cycle with two scales: the Portuguese 
version of RTL (Training Load Rating, Berglund and Säfström, 1994), and the CrlO scale of Borg (1982).

\section{a) The subjective perception of effort}

The intention of detecting and interpreting the sensations produced during physical exercise goes back to the 1950s. Borg $(1982,2000)$ considered the association between physiological events and the conscientious perception of effort signals in a three-dimensional model. The conceptualization of this model was based on the fact that, with the increase of intensity of exercise, alterations occur in the physiological processes and their perception by the individual. During or soon after an intense bout of physical exercise, the meaning of fatigue and perception of effort are very similar, with the later being related with the concept of intensity of the exercise, although there are important differences between the two concepts.

According to Borg (2000), the three components of the effort (perception, physiological, performance) give partially different information, and the variables concerned are not linearly related. In order to have a valid and complete estimate of the effort of an individual, it is important to integrate information from the three components of the effort.

Perception of effort can be defined trough the sensation of how heavy and exhausting a physical task is. This definition is basic, but does not offer any measure of the degree of the perceived effort. A measure of perception of effort is then the degree of experienced resistance and tension during physical work that is estimated with a specific classification method (Borg, 2000). Therefore, it is necessary to quantify the perception of effort, which is not a measure by itself.

\section{b) Scales of perception of effort}

The capacity to evaluate level of effort is highly developed in humans (Noble and Robertson, 1996; Borg, 2000; Dekerle et al, 2003). The association of sensations provides essential information to determine the degree of well being or level of threat. The perception of the effort is a control behaviour that uses information sources that are necessary to determine attitudes, which lead to the preservation of health and which play an important role in adaptation. Several perception scales have been used to attain this objective (Borg, 2000).

The evaluation of the energy cost of exercise can be made through the use of physiological techniques. However, it is the subjective cost of the exercise that determines if the activity will be continued or not, or if the 
rhythm of work needs to be increased or reduced. Assessment of subjective sensations is possible only through the use of personal estimates of the intensity of the associated sensations (Nobles and Robertson, 1996; ACSM, 2000; Dekerle et al, 2003).

Borg's scale was originally developed with the objective of monitoring perception of effort during cardiac rehabilitation. The initial intention was to construct a scale that reflected the correspondence between the perceived level of effort and cardiac frequency (RPE 6-20). Patients were taught to equate the intensities of work based on cardiac frequency (FC) to values on a subjective scale. The original RPE scale (Rating of Perceived Exertion) was intended to reflect the relationship between the perception of effort and the pulse rate, a linear relationship between cardiac frequency and exercise intensity. The scale extended from 6 (no sensation) to 20 (maximum effort). It was soon realized that the RPE 6-20 scale was not appropriate for studies that involved the associated sensation of physiological variables, such as lactate accumulation, whose behaviours are not linearly related with intensity of the exercise (Noble and Robertson, 1996).

A new scale of 10 was later introduced. It was better adjusted to the subjective sensations of physical tasks and is known as $\mathrm{CrlO}$ (Category Ratio scale, Borg, 1982). Zero refers to the total absence of sensation and 0,5 to slightly perceivable sensation. The category of maximum was placed beyond 10 (extremely difficult), after noting that athletes tended to never use this category (Noble and Robertson, 1996). Borg (2000) also reported a high correlation between the new scale and blood and muscle lactate levels.

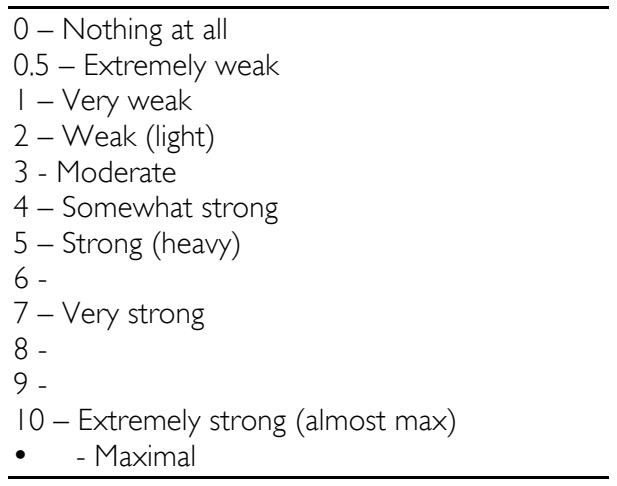

Figure I Borg's CrlO scale (adapted from Noble and Robertson, 1996).

Maglischo (1993) applied identical procedures with swimmers in an attempt to have them use the scales to monitor the intensity of training. One of the main 
advantages of using the scale was the fact that it was possible for the swimmers to progress in intensity of training not as a function of pre-set plans, but as a function of their perception of present capacity. The main disadvantage was a lack of quantification of intensities of training.

Table I. Borg's $\mathrm{CrIO}$ in relation to possible training effects and level of training (adapted from Maglischo. 1993)

\begin{tabular}{|c|c|c|c|}
\hline $\begin{array}{l}\text { Rating } \\
\text { scale }\end{array}$ & Perceived Effort & Possible Training Effects & Level of Training \\
\hline $7-8$ & $\begin{array}{l}\text { Hard but } \\
\text { manageable }\end{array}$ & $\begin{array}{l}\text { Overloads aerobic metabolism; work at or slightly } \\
\text { bellow the present anaerobic threshold }\end{array}$ & End-2 \\
\hline $5-6$ & Moderate effort & $\begin{array}{l}\text { Improves aerobic capacity. while providing some } \\
\text { relief from intense training }\end{array}$ & End-I \\
\hline $3-4$ & Easy & $\begin{array}{l}\text { Maintains aerobic endurance while recovering from } \\
\text { intense training }\end{array}$ & End-I \\
\hline $1-2$ & Very Easy & Is useful for warming up and swimming down & \\
\hline 9 & Very difficult & $\begin{array}{l}\text { Improves anaerobic capacity anaerobic and } \mathrm{VO}_{2} \\
\text { max; intensity is above the present anaerobic } \\
\text { threshold }\end{array}$ & $\begin{array}{l}\text { Lactate tolerance } \\
\text { End-3 }\end{array}$ \\
\hline 10 & Extremely difficult & Improves anaerobic metabolism & Lactate tolerance \\
\hline
\end{tabular}

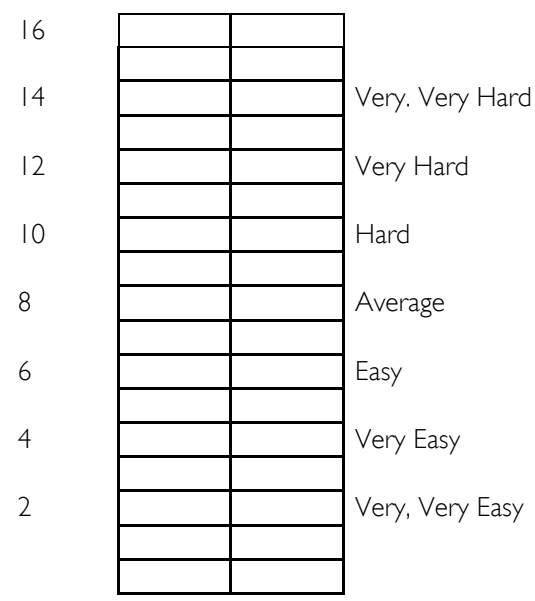

Figure 2 Rating of weekly training load (RTL ) scale (adapted from Berglund and Säfstrom, 1994)

Maglischo (1993) related the perception of effort determined by the CrIO scale with different levels of intensity of swim training (Table I). Bergglund and Säfström (1994) used another scale to identify perceived effort - the Rating of Weekly Training Load - RTL (Figure 2). In a study of 14 elite canoeists, 9 men 
and 5 women, a strait relationship was found between the RTL and the Profiling of Mood States questionnaire (POMS, Macnair, 1992). The proposed RTL scale ranged from 0 (rest) to 16 (very, very difficult).

\section{c) Factors that influence subjective perception of effort}

Perception of effort depends on the type of exercise and specific muscular work (Ben-Sira, 1986) The relationship between increased perception of effort and duration of the exercise is well established. There is a difference in the perception of effort between short and long duration exercises. In the first case, the individual tends to evaluate his effort in relation to his maximum capacity, while in the second case the individual might evaluate his effort with the objective of maintaining a particular level of effort during a greater period of time (Ben-Sira, 1986). When comparing equal productions of work, perceived effort is greater in low frequency/high resistance activities compared high frequency/low resistance activities (Mihevic, 198I)

With training adaptation, athletes tend to show lower levels of perceived effort for the same workload. There is some speculation about possible differences between men and women on the perception of effort. It has also been observed that, for the same type of physical task, women significantly classify the effort as heavier than men. The perception of effort and possible variations do not depend only on the intensity, duration and volume of the exercise, physical factors, and the environment and/or context, but also on psychological factors (Hamilton et al 1996). Factors related to motivation, emotional state and personality may also influence perception of effort. Highly motivated individuals (e.g., former athletes) tend to underestimate perception of effort. Emotional factors or temporary mood states (depression, anxiety, anger, joy) also influence the perception of effort (Noble and Robertson, 1996).

\section{METHODS}

The sample included 46 swimmers, 23 of each gender, from sport clubs of the same regional swimming association. The mean age for the total sample was $16.6 \pm 1.8$ years, $17.5 \pm 1.9$ years in males and $15.7 \pm 1.3$ years in females. The swimmers represented two competitive levels, 23 national swimmers with access to the Portuguese National Championships and 23 regional level swimmers. The age composition of the sample was primarily 16 to 18 years $(74 \%)$, which reflected the distribution of registered swimmers in the geographic area in which the study was conducted. All swimmers were informed of the objectives and procedures of the study and gave their written 
consent. In the case of younger athletes, written consent was given by their parents.

Table 2. Characteristics of the sample by age, sex and level of competition.

\begin{tabular}{cccccc}
\hline Age - group & \multicolumn{2}{c}{ National } & \multicolumn{2}{c}{ Regional } & \multirow{2}{*}{ Total } \\
\cline { 2 - 5 } & Male & Female & Male & Female & \\
\hline $14-15$ & & 3 & & 5 & 8 \\
$16-18$ & 12 & 6 & 7 & 9 & 34 \\
$19-24$ & 2 & & 2 & & 4 \\
\hline Total & 14 & 9 & 9 & 14 & 46 \\
\hline
\end{tabular}

Table 3. Body weight, stature and arm span by sex and level of competition

\begin{tabular}{lcccc}
\hline & \multicolumn{2}{c}{ National } & \multicolumn{2}{c}{ Regional } \\
\cline { 2 - 5 } & Female & Male & Female & Male \\
\hline Weight, $(\mathrm{kg})$ & $59.3 \pm 6.8$ & $63.2 \pm 5.7$ & $51.5 \pm 5.8$ & $68.5 \pm 10.5$ \\
Height, $(\mathrm{cm})$ & $165.8 \pm 4.5$ & $170.3 \pm 4.8$ & $158.9 \pm 6.6$ & $173.2 \pm 6.8$ \\
Armspan, $(\mathrm{cm})$ & $165.4 \pm 6.6$ & $176.1 \pm 4.9$ & $159.8 \pm 7.3$ & $179.7 \pm 8.1$ \\
\hline
\end{tabular}

All of the participants registered their level of perception of effort in a logbook recording using the two scales mentioned earlier. Entries were made at the beginning of each week, using the previous week as a reference. The beginning of the study was coincident with the first week of the season in September and ended after the main competition of the short season in March, for a total of 26 weeks. Although use of the scales was sufficiently simple, the swimmers had some initial difficulties in faithfully expressing their perception of effort.

Athletes were asked to adopt the following procedure. First, to look at the description that most closely matched the level of perception of effort of the last week of training, and to quantify this sensation. Several basic points need to be taken into consideration to use the scale correctly (Noble and Robertson, 1996):

I. To define perception of effort;

2. To be able to link the category of sensation to the associated value;

3. To explain the nature and use of the scale;

4. To explain that the perception can be localised or global depending on the objective of the study;

5. To be as honest as possible; 
Records were checked weekly to see if the process was done correctly. The daily workload was also registered. The use of the total distance swam does not clearly reflect the physiological stress produced at different levels of intensity. Training load was determined through the total amount of meters swam (volume) and also by the balance of the distance completed at each level of intensity (Maglischo, 1988; Mujika et al., 1995; Vadivieso, 200 I; Chatard and Mujika 1999). The use of indices of difficulty has been established in reference to the probable values of blood lactate accumulation normally associated with the different tasks of swimming training. Factors of intensity I, $2,3,4,6,8$ and 10 were matched with the volume done in each zone of intensity (I,II, III, IV, V, VI and VII). The magnitude of the load was then expressed in dimensionless units of load, or arbitrary units of load (AUL), quantified from the obtained rate of the sum of the volumes swam in each of the weighed zones multiplied by the respective index and the total volume effectively completed. This procedure allows adjustment to the exponential function determined by the curve of lactate accumulation in relation to the intensity of a swim.

The micro cycle or weekly load is quantified by two factors: volume total of meters swam, and intensity determined through the sum of the resulting dimensionless units of load of each training session.

Table 4. Intensity levels, objectives, average velocity on tasks, probable lactate, and stress indices for swim training

\begin{tabular}{l|l|c|c|c}
\hline $\begin{array}{l}\text { Intensity } \\
\text { Level }\end{array}$ & Objective & Average velocity & $\begin{array}{c}\text { Lactate } \\
\text { mmol..-1 }\end{array}$ & $\begin{array}{c}\text { stress } \\
\text { indices }\end{array}$ \\
\hline I & Warm-up and swim down & under 60\% & - & 1 \\
II & Aerobic capacity & $60-70 \%$ & $2-3$ & 2 \\
III & Anaerobic Threshold & $\approx 80 \%$ & $3-4$ & 3 \\
IV & Misted & $\approx 85 \%$ & $6-9$ & 4 \\
$V$ & Lactate Tolerance & $\approx 90 \%$ & $>8$ & 6 \\
$V I$ & Lactate Production & $\approx 95 \%$ & $>8$ & 8 \\
$V I I$ & Sprint & maximal & - & 10 \\
\hline
\end{tabular}

\section{RESULTS}

\section{a) Training load}

Because both regional and national level swimmers trained together it was important to verify if the training load between the two groups was indeed different or if the competitive level attained was due to other factors such as 
talent. The values of the training load show great variability due to the heterogeneous weekly training frequency of the two groups of swimmers. The national group had a weekly minimum frequency of five training sessions, and this criterion was fulfilled by all of the swimmers with few exceptions associated with injury or illness. During the study period, the national level group swam, on average, $27.7 \pm 4.3 \mathrm{~km}$ per week, and a total of $728.5 \pm 132.7$ $\mathrm{km}$ (Table 5). Intensity (weighed volume for intensity zone) corresponded to a

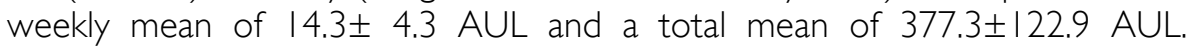
Corresponding values for regional level swimmers followed a similar pattern: weekly volume, $24.2 \pm 5.4 \mathrm{~km}$; total volume, $626.1 \pm 157.1 \mathrm{~km}$, intensity,

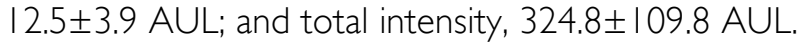

Table 5. Means, standard deviations and Student-t tests for training variables by level of competition: week volume, total volume, mean week intensity and sum of AUL.

\begin{tabular}{|c|c|c|c|c|}
\hline & Level & Mean \pm sd & $\mathrm{t}$ & $P$ \\
\hline Week Volume, (m ) & $\begin{array}{l}\text { National } \\
\text { Regional }\end{array}$ & $\begin{array}{l}27,742 \pm 4,270 \\
24,170 \pm 5,357\end{array}$ & 2.50 & $\leq 0.05$ \\
\hline Total Volume, (m ) & $\begin{array}{l}\text { National } \\
\text { Regional }\end{array}$ & $\begin{array}{l}728,470 \pm 132,722 \\
626,053 \pm 157,124\end{array}$ & 2.39 & $\leq 0.05$ \\
\hline $\begin{array}{l}\text { Mean week Intensity, } \\
\text { (AUL) }\end{array}$ & $\begin{array}{l}\text { National } \\
\text { Regional }\end{array}$ & $\begin{array}{l}14.3 \pm 4.3 \\
12.5 \pm 3.9\end{array}$ & 1.94 & n.s. \\
\hline$\sum$ of $(A \cup L)$ & $\begin{array}{l}\text { National } \\
\text { Regional }\end{array}$ & $\begin{array}{l}377.3 \pm 122.9 \\
324.8 \pm 109.8\end{array}$ & 1.53 & n.s. \\
\hline
\end{tabular}

The volumes of national level swimmers are significantly $(p \leq 0.05)$ higher than those of regional level swimmers (Table 5). When the workload was compared by specific weeks, differences were significant in seven weeks (Table 6). The overall differences in mean weekly intensity and mean total sum of intensity between national and regional swimmers, though higher in the former) are not significant (Table 5). However, mean weekly intensities differ significantly $(p \leq 0.05)$ in eight weeks (Table 7$)$. It seems that the training load fulfilled by the two groups of swimmers differed in the amount of meters swam. Regional swimmers, although fulfilling fewer kilometres, seem to dedicate more attention to tasks of higher intensity, trying to overcome insufficient exposure to the load. The criterion intensity (AUL), which express meters swam, weighted according to level of intensity, does not allow for the discrimination of workload between the two groups of swimmers. Nevertheless, the national group fulfilled a greater volume in high intensity

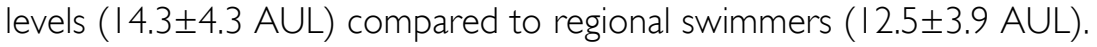


Table 6. Means and standard deviations of volume $(\mathrm{m})$ and Student-t tests for the weeks with a statistical significance between the national and regional swimmers.

\begin{tabular}{llccc}
\hline & Level & Mean \pm sd & $t$ & $\mathrm{p}$ \\
\hline \multirow{2}{*}{ VOL9 } & National & $32,519 \pm 7,821$ & 2.609 & $\leq 0.05$ \\
& Regional & $26,605 \pm 7,550$ & & \\
VOLII & National & $21,547 \pm 5,009$ & 2.298 & $\leq 0.05$ \\
& Regional & $18,025 \pm 5,380$ & & \\
VOLI5 & National & $36,730 \pm 9,030$ & 3.495 & $\leq 0.01$ \\
& Regional & $26,252 \pm 10,838$ & & $\leq 0.05$ \\
VOL16 & National & $29,105 \pm 9,808$ & 2.403 & \\
& Regional & $22,053 \pm 8,424$ & & $\leq 0.01$ \\
VOL18 & National & $34,359 \pm 6,227$ & 3.405 & \\
& Regional & $26,388 \pm 9,138$ & & $\leq 0.01$ \\
VOL21 & National & $31,704 \pm 8,529$ & 2.743 & \\
& Regional & $23,917 \pm 10,611$ & & $\leq 0.05$ \\
VOL24 & National & $29,404 \pm 6,116$ & 2.375 & \\
& Regional & $25,309 \pm 5,567$ & &
\end{tabular}

Table 7. Means and standard deviations for intensity (AUL) and Student-t tests for weeks with a statistical significance between national and regional swimmers.

\begin{tabular}{|c|c|c|c|c|}
\hline & Level & Mean $\pm \mathrm{sd}$ & $\mathrm{t}$ & $\mathrm{p}$ \\
\hline INT9 & $\begin{array}{l}\text { National } \\
\text { Regional }\end{array}$ & $\begin{array}{l}17.3 \pm 4.6 \\
\mid 4.2 \pm 5.1\end{array}$ & 2.16 & $\leq 0.05$ \\
\hline INTI | & $\begin{array}{l}\text { National } \\
\text { Regional }\end{array}$ & $\begin{array}{l}12.9 \pm 4.6 \\
10.0 \pm 3.7\end{array}$ & 2.29 & $\leq 0.05$ \\
\hline INTI3 & $\begin{array}{l}\text { National } \\
\text { Regional }\end{array}$ & $\begin{array}{l}14.9 \pm 5.2 \\
11.4 \pm 5.7\end{array}$ & 2.19 & $\leq 0.05$ \\
\hline INTI5 & $\begin{array}{l}\text { National } \\
\text { Regional }\end{array}$ & $\begin{array}{l}17.6 \pm 5.6 \\
12.7 \pm 5.6\end{array}$ & 2.86 & $\leq 0.01$ \\
\hline INTI 6 & $\begin{array}{l}\text { National } \\
\text { Regional }\end{array}$ & $\begin{array}{l}14.7 \pm 7.2 \\
10.4 \pm 4.9\end{array}$ & 2.16 & $\leq 0.05$ \\
\hline INTI8 & $\begin{array}{l}\text { National } \\
\text { Regional }\end{array}$ & $\begin{array}{l}18.2 \pm 5.5 \\
14.8 \pm 5.9\end{array}$ & 2.01 & $\leq 0.05$ \\
\hline INTI9 & $\begin{array}{l}\text { National } \\
\text { Regional }\end{array}$ & $\begin{array}{l}15.1 \pm 5.8 \\
\mid 1.2 \pm 5.4\end{array}$ & 2.38 & $\leq 0.05$ \\
\hline |NT2| & $\begin{array}{l}\text { National } \\
\text { Regional }\end{array}$ & $\begin{array}{l}14.2 \pm 5.3 \\
10.9 \pm 5.8\end{array}$ & 2.02 & $\leq 0.05$ \\
\hline
\end{tabular}

\section{b) Perception of effort}

There were no significant differences in perceived effort between male and female swimmers. Hence, the data are reported for the sexes combined. 


\section{b. I.) Perception of effort using the RTL scale}

Data for the perception of effort was analysed from the second week of training onward because some athletes initiated the season later and/or showed some initial difficulties in recording perception of effort. The lowest value of perception of effort, independently of the scale used, occurred in the beginning or at the end of the season. This behaviour was expected, since the athletes had just returned from holidays and the initial approach to training used low training load. The last week of the study corresponded to a period of recovery after the most important event of the season.

Table 8. Means, standard deviations and significant Student-t tests for perception of effort using the RTL scale in regional and national swimmers.

\begin{tabular}{ccccc}
\hline & \multicolumn{1}{c}{ Level } & Mean $\pm \mathrm{sd}$ & $\mathrm{t}$ & $\mathrm{P}$ \\
\hline \multirow{2}{*}{ RTL9 } & National & $9.77+1.74$ & 2.25 & $\leq 0.05$ \\
& Regional & $8.68+1.46$ & & $\leq 0.05$ \\
RTL14 & National & $9.45+1.87$ & 2.29 & $\leq 0.01$ \\
& Regional & $8.05+2.19$ & & $\leq 0.01$ \\
RTL22 & National & $10.05+1.80$ & 3.65 & $\leq 0.01$ \\
& Regional & $8.00+1.88$ & & $\leq 0.01$ \\
RTL23 & National & $10.23+1.77$ & 2.99 & $\leq 0.01$ \\
& Regional & $8.22+2.63$ & & \\
RTL24 & National & $11.14+3.21$ & 2.75 & \\
RTL25 & Regional & $8.65+2.84$ & & \\
& National & $10.30+2.30$ & 4.27 & \\
RTL26 & Regional & $7.83+1.56$ & & \\
& National & $9.30+2.42$ & 3.03 & \\
& Regional & $7.28+1.67$ & & \\
\end{tabular}

As shown in Table 8, national swimmers recorded the highest mean of perceived effort in the $24^{\text {th }}$ week of the season $(11.1 \pm 3.2)$. The lowest mean, $6.6 \pm 2.4$, was recorded in the $2^{\text {nd }}$ week of training. Looking at the highest value for the perception of effort and training workload, week 24 had a mean volume of $29403 \pm 6116 \mathrm{~km}$. Looking at intensity, this week was the second in a cycle of great intensity (17.2 $\pm 5.4 \mathrm{AUL})$. For regional swimmers, the highest value of perception of effort was recorded in the $7^{\text {th }}$ week $(9.6 \pm 2.3)$ and the lowest was recorded in the first week of the study (5.3 \pm 2.4$)$. Considering the dynamics of the training load of this group, the 7 th week corresponded to the week following the micro cycle which registered the highest values for volume and intensity. The slightly dislocated temporal coincidence can be explained by a process of insufficient recovery and by mechanisms of accumulated fatigue in these swimmers. 
The analysis of mean values for perception of effort shows that, at all times, national level swimmers presented higher mean scores than regional swimmers. Differences in perception of effort using the RTL scale between national and regional level swimmers were significant $(p \leq 0.05)$ in weeks 9,14 , $22,23,24,25$ and 26 . These weeks corresponded to moments of increasing training load. However, when analysing the temporal coincidence of training load and perception of effort, only at weeks 22 and 25 the differences in perception of effort were coincident with differences in volume swam by the two groups. For intensity, this occurred only at week 9 .

It seems that the swimmers, independently of competitive level, perceived the effort of the training tasks without isolating them from their daily activities. Factors such as the presence or lack of competitions, school duties, social relationships, and others, may contribute to the perception of effort.

Table 9. Means, standard deviations and significant Student-t tests for perception of effort using the $\mathrm{Cr} / \mathrm{O}$ scale in regional and national swimmers.

\begin{tabular}{|c|c|c|c|c|}
\hline & Level & Mean $\pm \mathrm{sd}$ & $\mathrm{t}$ & $\mathrm{p}$ \\
\hline Crlo I5 & $\begin{array}{l}\text { National } \\
\text { Regional }\end{array}$ & $\begin{array}{l}4.30 \pm 1.83 \\
3.71 \pm 1.35\end{array}$ & 2.425 & $\leq 0.01$ \\
\hline CrlO 17 & $\begin{array}{l}\text { National } \\
\text { Regional }\end{array}$ & $\begin{array}{l}5.13 \pm 2.24 \\
4.03 \pm 1.38\end{array}$ & 2.076 & $\leq 0.05$ \\
\hline Crlo 23 & $\begin{array}{l}\text { National } \\
\text { Regional }\end{array}$ & $\begin{array}{l}5.64 \pm 1.68 \\
3.59 \pm 1.65\end{array}$ & 4.403 & $\leq 0.01$ \\
\hline Crlo 24 & $\begin{array}{l}\text { National } \\
\text { Regional }\end{array}$ & $\begin{array}{l}6.27 \pm 2.69 \\
4.09 \pm 2.15\end{array}$ & 4.075 & $\leq 0.01$ \\
\hline Crlo 25 & $\begin{array}{l}\text { National } \\
\text { Regional }\end{array}$ & $\begin{array}{l}5.04 \pm 2.18 \\
3.52 \pm 1.12\end{array}$ & 3.015 & $\leq 0.01$ \\
\hline Crlo 26 & $\begin{array}{l}\text { National } \\
\text { Regional }\end{array}$ & $\begin{array}{l}4.72 \pm 2.20 \\
3.06 \pm 1.30\end{array}$ & 2.972 & $\leq 0.01$ \\
\hline Crlo 27 & $\begin{array}{l}\text { National } \\
\text { Regional }\end{array}$ & $\begin{array}{l}2.95 \pm 1.35 \\
2.07 \pm 1.02\end{array}$ & 2.366 & $\leq 0.05$ \\
\hline
\end{tabular}

\section{b.2.) Perception of Effort from CRIO Scale}

National level swimmers scored the highest values on the $\mathrm{CrlO}$ scale in week 24 (6.3 \pm 2.7$)$, and the lowest score at the beginning of the season (2.4 \pm 1.3$)$. The 24th week coincided with period of important volume and the intense participation in competition. Regional level swimmers recorded the highest score for perceived effort with the $\mathrm{Cr} / 0$ scale was in the $7^{\text {th }}$ week $(4.7 \pm 2.0)$ and the lowest at the beginning of the study $(1.9 \pm 1.3)$. These results are consistent with those obtained with the RTL scale, since the 7th week show the highest mean volume swam by this group. 
b.3.) Behaviour of the Sample Relative to Scale of Perception of Effort Used

The analysis of Table 10 shows in a consistent manner that national level swimmers recorded greater perception of the effort than regional swimmers. This helps to confirm the potential of these instruments in discriminating between athletes in the same sport who have different levels of participation. Analysis of mean values for perception of effort with both scales showed significant differences by level of swimming competition.

Table 10. Means, standard deviations and Student-t tests for perception of effort using the $\mathrm{RTL}$ and $\mathrm{CrIO}$ scales with regional and national swimmers.

\begin{tabular}{llllll}
\hline & Level & $N$ & Mean \pm sd & $t$ & $P$ \\
\hline CRI0 & National & 23 & $4.25 \pm 0.99$ & 3.293 & $\leq 0.01$ \\
\multirow{2}{*}{ RTL } & Regional & 23 & $3.57 \pm 0.76$ & & $\leq 0.01$ \\
& National & 23 & $9.09 \pm 0.88$ & 3.725 & \\
& Regional & 23 & $8.05 \pm 1.01$ & & \\
\hline
\end{tabular}

The values of perception of effort over the 26 weeks of the study with the RTL scale showed a higher mean for national $(9.1 \pm 0.9)$ than for regional $(8.0 \pm 1.0)$ swimmers $(p \leq 0.01)$. The mean value of national level swimmers with the RTL scale fell between the "average" and "hard" categories, while that of regional swimmers fell in the "average" category.

Table I I. Means and standard deviations for perception of effort with the RTL and CrIO scales by age group.

\begin{tabular}{lccc}
\hline & Age-Group & $N$ & Mean \pm sd \\
\hline RTL & I4-15 & 9 & $8.84 \pm 0.62$ \\
& $16-18$ & 33 & $8.60 \pm 1.07$ \\
$19-24$ & 4 & $7.68 \pm 1.68$ \\
& Total & 46 & $8.57 \pm 1.08$ \\
& & & \\
Crl0 & 9 & $3.43 \pm 0.66$ \\
& $14-15$ & 33 & $4.23 \pm 0.94$ \\
& $16-18$ & 4 & $3.40 \pm 1.22$ \\
& 19-24 & 46 & \\
\hline
\end{tabular}


With the CrlO scale, the mean value for perception of effort for national swimmers was $4.3 \pm 1.0$, which corresponded to the "somewhat strong" category. The mean value for regional swimmers was 3.6 \pm 0.8 , which corresponded to the "moderate" and "somewhat strong" categories. The difference between groups of swimmers was significant $(p \leq 0.01)$. This result may be related to several factors, such as more demanding training in volume and intensity, as well as participation in competitions of greater significance.

Only during one of the 26 weeks of the season was a maximum mean value of $10.5 \pm 2.5$ recorded, which corresponded to a perception of the effort between "hard" and "very hard" for national swimmers, while the regional group recorded a maximum mean of $9.6 \pm 2.3$, which was anchored in the "hard" category. As noted by Borg (2000), athletes tend to underestimate their perception of effort. It is thus possible that throughout the season, the natural adaptation to the training tasks can lead to a disregard of the difficulty of the workloads.

Although numbers were small in some age groups, there were not significant differences in perception of effort by age within each sex (Table II). And as noted earlier, males and females did not differ significantly in perception of effort on either scale. However, the difference with the CrlO scale approached significance (Table 12).

Table 12. Means and standard deviations for perception of effort with the RTL and CrIO scales by sex.

\begin{tabular}{ccccccc}
\hline & & $N$ & Mean \pm sd & $t$ & $d f$ & $p$ \\
\hline CRI0 & Male & 23 & $4.26 \pm 1.01$ & 1.858 & 44 & n.s. \\
& Female & 23 & $3.74 \pm 0.88$ & & & \\
RTL & Male & 23 & $8.70 \pm 1.21$ & 0.84 & 44 & n.s. \\
& Female & 23 & $8.44 \pm 0.94$ & & & \\
\hline
\end{tabular}

\section{Correlational analysis}

Correlations among variables are summarized in Table 13. The two scales of perception of effort are highly correlated, $r=0.95(p \leq 0.0 \mathrm{l})$. Training load components are also strongly correlated with perception of effort as assessed by both scales. Correlations for volume were $r=0,84$ and $r=0.85(p \leq 0.01)$, respectively, for the $\mathrm{CrlO}$ and $\mathrm{RTL}$ scales. Corresponding correlations for intensity were, respectively, $r=0.73$ and $r=0.7 \mathrm{I}(\mathrm{p} \leq 0.0 \mathrm{I})$ for the $\mathrm{Cr} / 0$ and $\mathrm{RTL}$ scales. 
Table 13. Person's correlation coefficient for the perception of effort determined for the RTL and $\mathrm{CrlO}$ scales and workload - volume $(\mathrm{km})$ and intensity (AUL).

\begin{tabular}{cccc}
\hline & RTL & Volume & Intensity \\
\hline Crl0 & $0.95^{* *}$ & $0.84^{* *}$ & $0.73^{* * *}$ \\
RTL & & $0.85^{* * *}$ & $0.71^{* * *}$ \\
& & & \\
\hline
\end{tabular}

米 $p<0.01$

\section{CONCLUSION}

The results highlight the validity of using scales of perception of effort to monitor and control training. Higher values of perceived effort in national level swimmers, who follow higher training loads, were observed.

Although the majority of this sample was 16 to 18 years old, age did not seem to influence perception of effort scores. This may partially be explained by the adoption of similar training loads by all age groups. Sex differences in perception of effort were not significant, which may also be explained by the adoption of similar training loads by male and female swimmers. This is generally a characteristic of training among swimmers. There may be sex differences in sports with a greater variability of tasks and training intensities.

Perceived effort differs between the two performance levels during a period when participation in competition is more frequent, i.e., the final 6 to 7 weeks. It appears that perception of effort is affected by participation in competitions and/or the approach of important competitions.

As a final mark is suggest that the use of perception of effort scales can work as auxiliary instruments to monitor swimming training. The scales showed strong correlation with the volume and intensity of training. Both scales (CRIO and RTL) have similar potential to function as instruments to help monitor and control the training process in swimming.

\section{REFERENCES}

American College of Sports Medicine. (2000) Guidelines for Exercise Testing and Prescription. $6^{\text {a }}$ Ed. Baltimore, Williams \& Williams.

Dekerle J, Baron B, Dupont L, Garcin M, Vanvelcenaher J, \& Pelayo, P. (2003). Effect of incremental and submaximal constant load tests protocol on perceived exertion (CRI0) values. Percept Mot Skills, 96(3): 896-904. 
Ben-Sira D (1986). The Perception of effort during physical exercise. In Zaichowsky L. \& Fuchs C (Eds) The psychology of motor behaviour: development, control, learning and performance (pp |75-191). Ithaca, NY. Movements Publications, Inc.

Berglund B, Safstrom H (1994). Psychological monitoring and modulation of training load of world-class canoeists. Medicine \& Science in Sports \& Exercise, vol. 26 (8): 1036- 1040.

Borg G (1982). Psychophysical bases of perceived exertion. Medicine and Science in Sports and Exercise Vol. 14 (5): 377-38I.

Borg G (1985). An introduction to Borg's RPE scale. Ithaca, NY. Mouvement Publications.

Borg G, Ljunggren G, Ceci R (1985). The increase of perceived exertion, aches and pain in the legs, heart rate and blood lactate during exercise on a bicycle ergometer. Eur. J. Applied Physiology, 54: 343-349.

Borg G (2000). Escalas de Borg para a Dor e o Esforço Percebido. São Paulo. Manole.

Chatard, JC, \& Mujika, I ( 1999). Training Load and Performance in Swimming. In KL

Keskinen \& PV Komi \& AP Hollander (Eds.), Biomechanics and Medicine in

Swimming VIII (pp. 429-434). Jyvaskyla: Gummerus Printing.

Hamilton, AL, Killian, KJ, Summers, E, \& Jones, NL (1996). Quantification of intensity of sensations during muscular work by normal subjects. J Appl Physiol, 8I (3): I I56| 161 .

McNair DM, Lorr M, Droppleman LF (1992). Profile of Mood States Manual. Educational and Industrial Testing Service. San Diego

Maglischo EW (1988). Application of energy metabolism to swimming training. In: Swimming Science V (pp 209-2 I8)., Champaign, IL. Human Kinetics.

Maglischo EW (1993). Swimming even faster. Mayfield Publishing Company

Mihevic PM (1981). Sensory cues for perceived exertion: a review. Medicine and Science in Sports and Exercise, vol 13, (3): 150-163.

Mujika I, Chatard JC, Busso T, Geyssant A, Barale F, Lacoste L (1995). Effects of Training on Performance in Competitive Swimming Can. J. Appl. Physiol. 20: 395406.

Noble B \& Robertson R (1996). Perceived Exertion. USA: Human Kinetics.

Rushall B (1995). Training prescription: the relationships of technique, overload, and specificity. Carlile Coaches' Forum. Vol 2 (4). San Diego State University.

Valdeviesso F, Navarro Feal AR ( 200I). Planificación y Control del Entrenamiento en Natación. Madrid. Editorial Gymnos.

Weltman A (1995). The Blood Lactate response to exercise. Champaign. IL: Human Kinetics

Wilmore J, Costill D, (1994). Physiology of Sport and Exercise. Champaign, IL. Human Kinetics. 